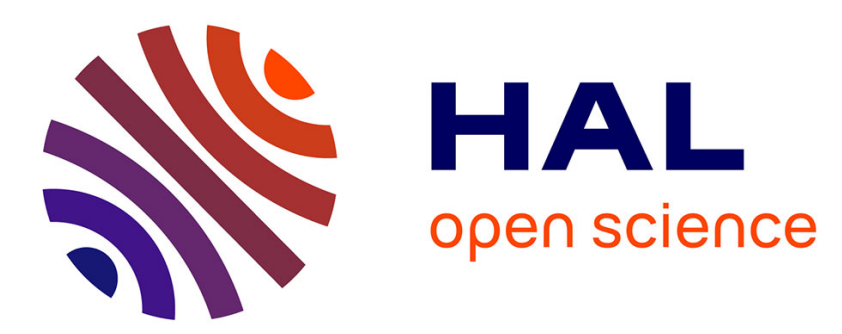

\title{
Potent Anticancer Efficacy of First-In-Class Cu II and Au III Metaled Phosphorus Dendrons with Distinct Cell Death Pathways
}

Liang Chen, Yu Fan, Jieru Qiu, Regis Laurent, Jin Li, Jérôme Bignon, Serge Mignani, Anne-Marie Caminade, Xiangyang Shi, Jean Pierre Majoral

\section{To cite this version:}

Liang Chen, Yu Fan, Jieru Qiu, Regis Laurent, Jin Li, et al.. Potent Anticancer Efficacy of First-InClass Cu II and Au III Metaled Phosphorus Dendrons with Distinct Cell Death Pathways. Chemistry - A European Journal, 2020, 26 (26), pp.5903-5910. 10.1002/chem.202001014 · hal-02623761

\section{HAL Id: hal-02623761 https://hal.science/hal-02623761}

Submitted on 2 Nov 2020

HAL is a multi-disciplinary open access archive for the deposit and dissemination of scientific research documents, whether they are published or not. The documents may come from teaching and research institutions in France or abroad, or from public or private research centers.
L'archive ouverte pluridisciplinaire HAL, est destinée au dépôt et à la diffusion de documents scientifiques de niveau recherche, publiés ou non, émanant des établissements d'enseignement et de recherche français ou étrangers, des laboratoires publics ou privés. 


\title{
Potent anticancer efficacy of first-in-class $\mathrm{Cu}$ (II) and $\mathrm{Au}$ (III) metaled phosphorus dendrons with distinct cell death pathways
}

\author{
Liang Chen, Yu Fan, Jieru Qiu, Régis Laurent, Jin Li, Jérôme Bignon, Serge Mignani, *Anne-Marie \\ Caminade, Xiangyang Shi* and Jean-Pierre Majoral*
}

\begin{abstract}
First-in-class $\mathrm{Cu}(\mathrm{II})$ and $\mathrm{Au}(\mathrm{III})$ metaled phosphorus dendrons were synthesized and showed significant antiproliferative activity against several aggressive breast cancer cell lines. The data suggest that the cytotoxicity increases with reducing the length of the alkyl chains, whereas the replacement of $\mathrm{Cu}$ (II) by $\mathrm{Au}(\mathrm{III})$ considerably increases the antiproliferative activity of metaled phosphorus dendrons. Very interestingly, we found that the cell death pathway is related to the nature of the metal complexed by the plain dendrons. $\mathrm{Cu}(\mathrm{II})$ metaled dendrons showed a potent caspasedependent cell death pathway; whereas $\mathrm{Au}(\mathrm{III})$ metaled dendrons displayed a caspase-independent apoptotic pathway. The complexation of plain dendrons with $\mathrm{Au}(\mathrm{III})$ increased the cellular lethality versus dendrons with $\mathrm{Cu}(\mathrm{II})$ and promoted the translocation of Bax into the mitochondria and the release of Cytochrome C (Cyto C).
\end{abstract}

\section{Introduction}

The discovery of cisplatin (cis-diaminodichloroplatinum(II)) in 1965 by Rosenberg, through a serendipitous approach, played a pivotal role in the discovery of many metallo-drugs used today in the treatment of cancer. ${ }^{[1]}$ Cisplatin is the first approved anticancer drug based on an inorganic complex, and it is now used to treat a wide range of cancers. ${ }^{[2]}$ This built the foundation of the modern era for the rapid development of anticancer metallo-drugs using several types of metals such as palladium, ruthenium, osmium, iron, gold, copper, and rhodium. ${ }^{[3]}$ Note that other metals such as nickel, cadmium, chromium, and arsenic induced carcinogenesis effects. ${ }^{[4]}$ The main limitation of metallo-drugs is their potential instability in the blood and their oxidation profile. ${ }^{[5]}$

[a] L. Chen, Y. Fan, J. Qiu, J. Li, Prof. Dr. S. Mignani, Prof. Dr. X. Shi State Key Laboratory for Modification of Chemical Fibers and Polymer Materials, College of Chemistry, Chemical Engineering and Biotechnology,

Donghua University

Shanghai 201620, People's Republic of China

E-mail: xshi@dhu.edu.cn

[b] L. Chen, J. Qiu, Dr. R. Laurent, Prof. Dr. A. M. Caminade, Prof. Dr. J. P. Majoral

Laboratoire de Chimie de Coordination du CNRS

31077 Toulouse Cedex 4, France

E-mail:majoral@lcc-toulouse.fr

[c] L. Chen, J. Qiu, Dr. R. Laurent, Prof. Dr. A. M. Caminade, Prof. Dr. J. P. Majoral

Université de Toulouse

31077 Toulouse CEDEX 4, France

[d] Prof. Dr. J. Bignon

Institut de Chimie des Substances Naturelles du CNRS

91198 avenue de la Terrasse, Paris Gif-sur-Yvette Cedex, France

[e] Prof. Dr. S. Mignani

Université Paris Descartes, PRES Sorbonne Paris Cité, CNRS UMR

860, Laboratoire de Chimie et de Biochimie Pharmacologiques et

Toxicologique

45, rue des Saints Pères, 75006 Paris, France

E-mail: serge_mignani@orange.fr

[f] Prof. Dr. X. Shi, Prof. Dr. S. Mignani

CQM - Centro de Química da Madeira, Universidade da Madeira,

Campus da Penteada, 9020-105 Funchal, Portugal
Nanotechnology represents a huge multidisciplinary field encompassing chemistry, biology, physics, engineering, etc., and it has appeared to be a benefit to humanity in a wide variety of multidisciplinary domains including therapeutic domains (termed nanomedicine) such as in the fields of cancer, cardiovascular disease, and central nervous system disorders. ${ }^{[6]}$ Thus, the rational design of nanoparticles encapsulating or complexing anticancer drugs (such as doxorubicin liposomes $\left(\right.$ Doxil $\left.^{\circledR}\right)$ and paclitaxel albumin $\left(\right.$ Abraxane ${ }^{\circledR}$ ), which have been U.S. Food and Drug Administration (FDA) approved in 1995 and 2005 , respectively) plays a pivotal role to treat cancer. ${ }^{[7]}$

Within the nanomedicine field, the remarkably unique and tunable properties of monodisperse dendrimers and dendrons have offered the opportunity to open new avenues in the domain of oncology. They are mainly used as nanocarriers of drugs, small interfering RNA (siRNA), and anti-sense therapy (gene delivery), as well as in diagnostics. ${ }^{[8]}$ Dendrimers are hyperbranched globular macromolecules with a 'cauliflower shape'. They are repetitively branched molecules with a branched mode of growth and are prepared by iterative reactions. Dendrons are also monodisperse, owning wedgeshaped dendrimer sections with multiple terminal groups. They generally have a single distinct chemically addressable group at the focal point. ${ }^{[9]}$
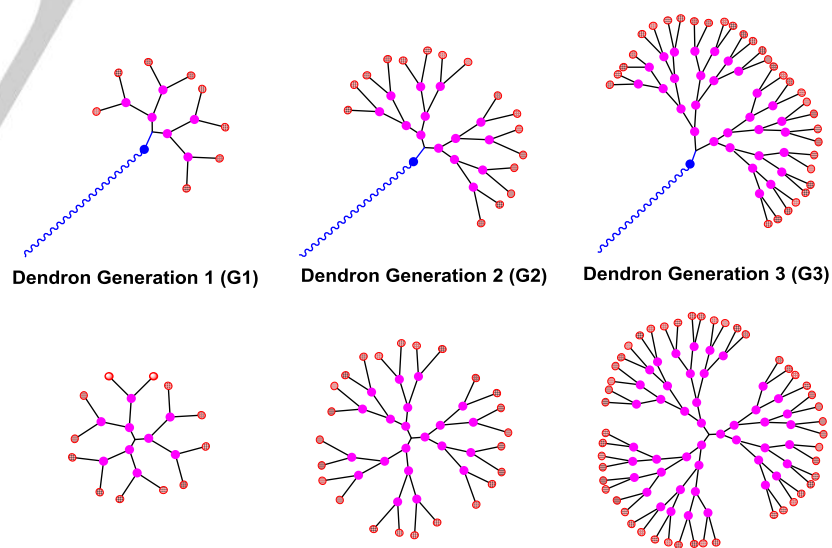

Dendrimer Generation 1 (G1) Dendrimer Generation 2 (G2) Dendrimer Generation 3 (G3)

- Functional group on the surface

- Scaffold groups

Hydrophobic chain

Figure 1. Schematic 2D chemical structures of dendrons and corresponding dendrimers.

The 2D schematic difference between dendrons and dendrimers (generations 1,2 and 3) is illustrated in Figure 1. Due to their high degree of molecular uniformity, and perfect control of their shape, size, and surface groups, dendrimers and dendrons offer a variety of drug-design options and important suitable alternatives for the delivery of active biomolecules in oncology applications. ${ }^{[9-10]}$ Interestingly, several examples of 
dendrimer-conjugated metallo-drugs have been pointed out such as poly (alkylidenimine) dendrimers functionalized with $\mathrm{Ru}$ metal, ${ }^{[11]}$ and multivalent $\mathrm{Cu}(\mathrm{II})$-conjugated phosphorus dendrimers developed by several of us (S. M., A-M. C.; and J-P. M.). ${ }^{[12]}$ Thus, in 2013, novel $\mathrm{Cu}(\mathrm{II})$-phosphorus dendrimers generations $1(12 \mathrm{Cu}(\mathrm{II})), 2(24 \mathrm{Cu}(\mathrm{II}))$, and $3(48 \mathrm{Cu}(\mathrm{II}))$ - were prepared in good overall yield and displayed moderate to good antiproliferative properties against KB (epidermal carcinoma) and leukaemia HL60 cell lines (promyelocyte). The most potent phosphorus dendrimer came from generation 3 (termed 1G3$\mathrm{Cu}(\mathrm{II})$, Figure $\mathrm{S} 1$ ), with $48 \mathrm{Cu}$ (II) on the surface. 1G3-Cu(II) also showed sustainable antiproliferative activities against a panel of tumor cells such as HCT116 (human colon cancer), MCF7 (hormone-responsive breast cancer), OVCAR8 (ovarian carcinoma), and U87-MG (human glioblastoma-astrocytoma, epithelial-like) cancer cell lines. Outstandingly, 1G3-Cu(II) demonstrated a good safety ratio based on its $\mathrm{IC}_{50}$ non-cancer cells $/ \mathrm{IC}_{50}$ cancer cells ratio. MRC5 (proliferative human lung fibroblasts) and the quiescent EPC (endothelial progenitor cells, Cyprinus carpio) have been selected as non-cancer cell lines. The $I_{50}$ S against cancer cell lines ranged between $\sim 200$ and $\sim 800 \mathrm{nM}$, and against non-tumor cell lines between 800 and $1400 \mathrm{nM}$. Recently, Del Olmo, N. S et al. introduced the same bidentate chelator with $\mathrm{Cu}(\mathrm{II})$ in the carbosilane dendrimer series affording similar in vitro antiproliferative activities. ${ }^{[13]}$

Thereafter, in line with our previous work (vide supra), S. Mignani and J-P. Majoral et al. conjugated the most potent G3 phosphorus dendrimer with $\mathrm{Au}(\mathrm{III})$ in place of $\mathrm{Cu}$ (II) giving 1G3$\mathrm{Au}(\mathrm{III}){ }^{[12,14]}$ The complexation of the dendrimer with $\mathrm{Au}(\mathrm{III})$ strongly increased the antiproliferative activity against both KB and leukemia HL-60 cancer cell lines versus the corresponding 1G3-Cu(II), showing $I_{50} \mathrm{~S}$ in the low nanomolar range while maintaining a good safety ratio.

Taking inspiration from the potent antiproliferative activity of the phosphorus dendrimers $1 \mathrm{G} 3-\mathrm{Cu}$ (II) and 1G3-Au(III), in this manuscript we describe the synthesis and strong antitumor properties of four first-in-class multivalent $\mathrm{Cu}(\mathrm{II})$ and $\mathrm{Au}(\mathrm{III})$ metaled phosphorus dendrons (generation 1, 10 terminal groups) bearing two different types of linear alkyl chains (termed 1GC11-Cu(II), 1GC17-Cu(II), 1GC11-Au(III) and 1GC17-Au(III)) Outstandingly, $\mathrm{Cu}(\mathrm{II})$-phosphorus dendrons and $\mathrm{Au}(\mathrm{III})$ phosphorus dendrons displayed a distinct cell death pathway.

\section{Results and Discussion}

As shown in Figure 2, we prepared four different dendrons bearing two distant linear alkyl chains $\left(\mathrm{C}_{11} \mathrm{H}_{23}\right.$ and $\left.\mathrm{C}_{17} \mathrm{H}_{35}\right)$, and bearing ten $\mathrm{N}$-(pyridin-2-ylmethylene) ethanamine groups to complex $\mathrm{Cu}(\mathrm{II})$ and $\mathrm{Au}$ (III) to afford 1GC11-Cu(II), 1GC17-Cu(II), 1GC11-Au(III) and 1GC17-Au(III). These dendrons were prepared with good overall yields. The regioselective condensation of 4-hydroxybenzaldehyde (2) with the hexachlorocyclotriphosphazene (1) (THF, room temperature) afforded the $\mathbf{A B}_{5}$ monomer (3) in $76 \%$ yield. Then, $\mathbf{3}$ was treated with the amino-phenol-derivatives $\mathbf{4 a}$ and $\mathbf{4 b}$ (cesium carbonate, $\mathrm{THF}$, room temperature) to give the dendrons $\mathbf{5 a}$ and $\mathbf{5 b}$ in $85 \%$ yield. Thereafter, the resulting dendrons were treated with (1methylhydrazinyl)phosphonothioic dichloride (dichloromethane, room temperature) to afford $7 \mathbf{a}$ and $7 \mathbf{b}(90 \%$ yield), which were treated with 4-(2-((pyridin-2ylmethylene)amino)ethyl)phenol (8) (cesium carbonate, THF, room temperature), to give the dendrons $9 \mathrm{a}$ and $\mathbf{9 b}$ in $85 \%$ yield. Finally, the complexation of $9 a$ and $9 b$ with $\mathrm{CuCl}_{2}$ and $\mathrm{HAuCl}_{4}$ (dimethylformamide, room temperature) gave the corresponding metaled-dendrons 1GC11-Cu(II), 1GC17-Cu(II), 1GC11-Au(III) and 1GC17-Au(III) in 78-81\% yield. 1GC11-Cu(II) and 1GC17$\mathrm{Cu}$ (II) contain $10 \mathrm{CuCl}_{2}$ on their surface, whereas 1GC11-Au(III) and 1GC17-Au(III) incorporate $10\left[\mathrm{AuCl}_{2}\right]^{+} /\left[\mathrm{AuCl}_{4}\right]^{-}$on their surface. Monitoring the progress of the reaction was performed using ${ }^{31} \mathrm{P} N M R,{ }^{1} \mathrm{H}$ NMR, and ${ }^{13} \mathrm{C}$ NMR spectral analysis and inductively coupled plasma-optical emission spectrometry (ICPOES) analysis, which corroborate the structure of the metaled phosphorus dendrons (Supporting Information).

The primary objective of this study was to investigate the antiproliferative activity of the four metallo-dendrons prepared. Two different breast cancer cell lines were chosen for antiproliferative activity: 1) 4T1, mouse breast adenocarcinoma cells which are highly tumorigenic and invasive unlike most tumor models used; and 2) MCF-7, human breast adenocarcinoma cells which are widely studied as epithelial cancer cells, as well the normal fibroblast NIH-3T3 cells and the human fetal lung fibroblast cells MRC5 for safety purposes.

Firstly, we compared the anti-proliferative properties of two phosphorus dendrons bearing $\mathrm{Cu}(\mathrm{II})$ as the metal moiety and with two different linear alkyl chains, C11 (1GC11-Cu(II)) and C17 (1GC17-Cu(II)) against 4T1, MCF-7, NIH-3T3, and MRC5 cells. As shown in Table 1, in the absence of metal ions, the dendrons $9 \mathrm{a}$ and $9 \mathrm{~b}$ did not display any inhibitory effect on cell proliferation $\left(\mathrm{IC}_{50} \mathrm{~S}>100 \mu \mathrm{M}\right)$ against the two cell lines (MCF-7 and NIH-3T3), whereas the introduction of $\mathrm{Cu}(\mathrm{II})$ increased the antiproliferative activity against $4 \mathrm{~T} 1$ and MCF-7 cells with $\mathrm{IC}_{50} \mathrm{~S}$ between 0.6 and $2.8 \mu \mathrm{M}$. The dendron 1GC11-Cu(II) showed safety ratios of $\sim 2.5 \quad\left(\mathrm{IC}_{50} \quad \mathrm{NIH}-3 \mathrm{~T} 3 / \mathrm{IC}_{50} \quad 4 \mathrm{~T} 1\right), \quad \sim 4 \quad\left(\mathrm{IC}_{50}\right.$ MRC5/IC $504 T 1), 1$ (IC 50 NIH-3T3/IC 50 MCF-7), and $1.7\left(\right.$ IC $_{50}$ MRC5/IC 50 MCF-7), whereas, the dendron 1GC17-Cu(II) showed safety ratios of $\sim 4\left(\mathrm{IC}_{50} \mathrm{NIH}-3 \mathrm{~T} 3 / \mathrm{IC}_{50} 4 \mathrm{~T} 1\right), \sim 3\left(\mathrm{IC}_{50}\right.$ MRC5/IC $504 T 1), ~ 1.5$ (IC 50 NIH-3T3/IC 50 MCF-7), and 1 (IC 50 MRC5/IC 50 MCF-7). Clearly, these data demonstrated that the complexation of phosphorus dendrons with $\mathrm{Cu}(\mathrm{II})$ boosts the antiproliferative activity versus nonmetallic dendrons, and the safety ratio was related to the metal considered, to the nature of the alkyl chain and to the nature of normal and tumoral cells used. 


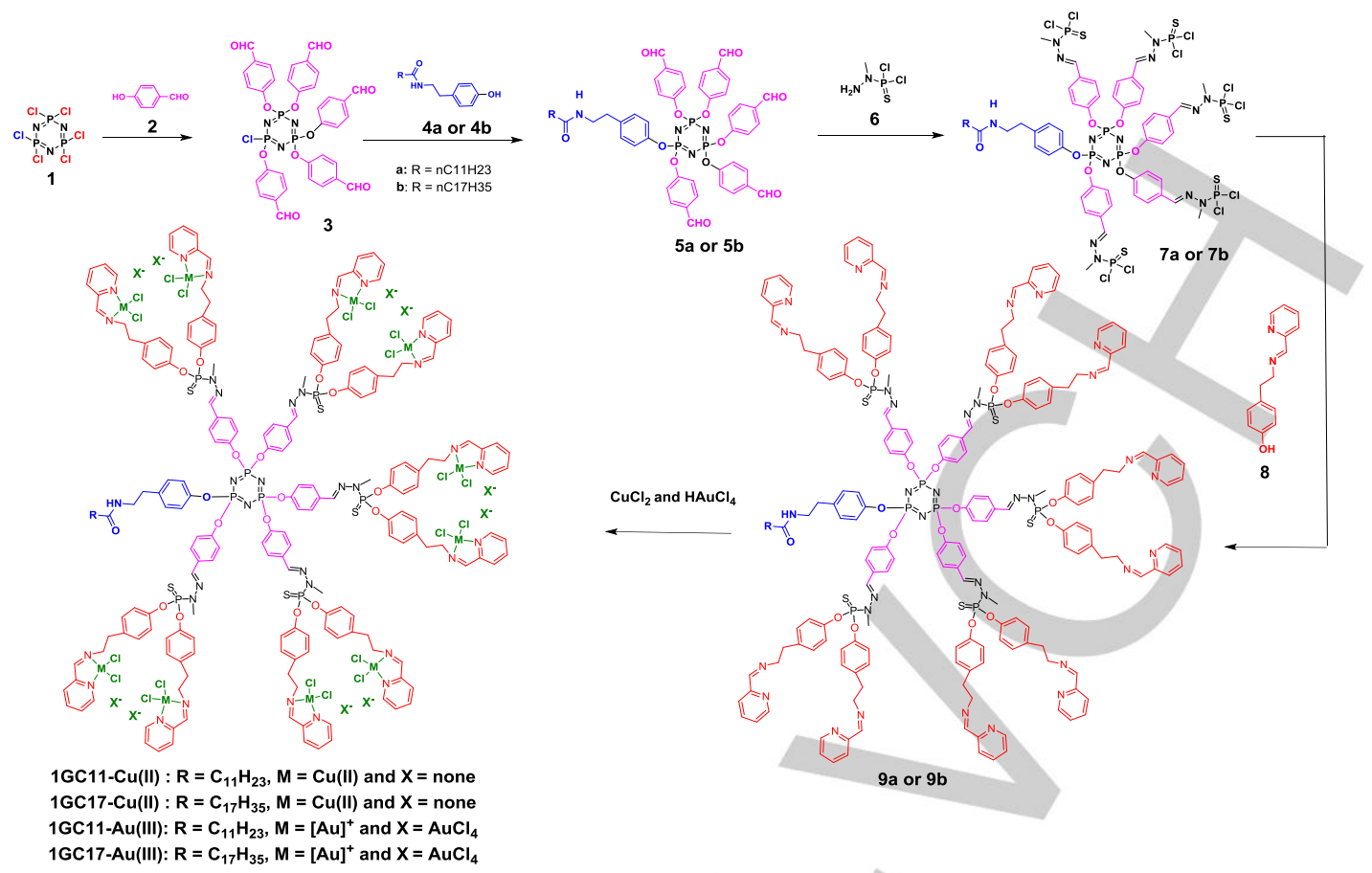

Figure 2. Synthetic pathways of $9 a, 9 b$, and metaled phosphorus dendrons 1GC11-Cu(II), 1GC17-Cu(II), 1GC11-Au(III), and 1GC17-Au(III).

Thereafter, our attention was directed to the replacement of $\mathrm{Cu}$ (II) by $\mathrm{Au}$ (III). Previously, we showed that the replacement of $\mathrm{Cu}(\mathrm{II})$ in the phosphorus dendrimer generation 3 (1G3-Cu(II)) by $\mathrm{Au}(\mathrm{III})$ (1G3-Au(III)) strongly boosted the antiproliferative activities against the KB cancer cell lines and HL60 (promyelocytic) cell lines (vide supra) while keeping good a safety ratio. In this direction, we prepared the metallo-dendrons 1GC11-Au(III) and 1GC17-Au(III) (Figure 2). The antiproliferative activities of 1GC11-Au(III) and 1GC17-Au(III) are presented in Table 1.

Table 1. Anti-proliferative activities of dendrons 9a, 9b, 1GC11-Cu(II), 1GC17-Cu(II), 1GC11-Au(III)) and 1GC17-Au(III).

\begin{tabular}{|c|c|c|c|c|}
\hline & \multicolumn{4}{|c|}{$\mathrm{IC}_{50}(\mu \mathrm{M})^{[\mathrm{a}]}$} \\
\hline & $4 T 1^{*}$ & MCF-7* & NIH-3T3* & MRC5* \\
\hline $9 a$ & $>100$ & $>100$ & $>100$ & NT \\
\hline $9 b$ & $>100$ & $>100$ & $>100$ & NT \\
\hline 1GC11-Cu(II) & $0.585 \pm 0.11$ & $1.489 \pm 0.27$ & $1.491 \pm 0.22$ & $2.46 \pm 1.20$ \\
\hline 1GC17-Cu(II) & $1.025 \pm 0.09$ & $2.755 \pm 0.25$ & $4.075 \pm 0.65$ & $2.66 \pm 0.64$ \\
\hline 1GC11-Au(III)) & $0.164 \pm 0.04$ & $0.286 \pm 0.07$ & $0.468 \pm 0.12$ & $2.71 \pm 0.71$ \\
\hline 1GC17-Au(III) & $0.339 \pm 0.06$ & $0.802 \pm 0.15$ & $0.132 \pm 0.06$ & $3.18 \pm 0.27$ \\
\hline
\end{tabular}

${ }^{\text {[a] }}$ Cells were incubated dendrons at eight concentrations $(0.01$ to $50 \mu \mathrm{M})$ for $72 \mathrm{~h}$ and the data were represented as "mean \pm SD" $(n=3)$.

As observed in the phosphorus dendrimer series (vide supra), the replacement of $\mathrm{Cu}$ (II) by $\mathrm{Au}$ (III) strongly improved the antiproliferative activity. 1GC11-Au(III) and 1GC17-Au(III) showed $\mathrm{IC}_{50} \mathrm{~S}$ of $\sim 0.16-0.8 \mu \mathrm{M}$ against $4 \mathrm{~T} 1$ and MCF-7 cells. The improvement was between 3- and 5-times in favor of $\mathrm{Au}(\mathrm{III})$ versus $\mathrm{Cu}$ (II). Interestingly, the safety ratios for 1GC11-Au(III) were $\sim 3$ and $\sim 1.7$, for $4 \mathrm{~T} 1$ and MCF-7 versus NIH-3T3 cells, and $\sim 17$ and $\sim 9$, for $4 \mathrm{~T} 1$ and MCF-7 versus MCR5 cells, respectively. The safety ratio for 1 GC17-Au(III) were $\sim 0.3$ and $\sim 0.1$, for $4 \mathrm{~T} 1$ and MCF-7 versus NIH-3T3 cells, and $\sim 11$ and $\sim 4$, for $4 \mathrm{~T} 1$ and MCF-7 versus MCR5 cells, respectively. As previously mentioned, the safety ratio for the considered metal is related to the nature of the alkyl chain and to the nature of normal cell lines used.

Taken together, these data fully confirm the strong anticancer profile of phosphorus dendrons bearing linear alkyl chains $\left(\mathrm{C}_{11} \mathrm{H}_{23}\right.$ and $\left.\mathrm{C}_{17} \mathrm{H}_{35}\right)$ and complexed with $\mathrm{Au}(\mathrm{III})$. As in the copper series, the nature of the alkyl chain plays a major role in the safety ratio profile.

Table 2. Anti-proliferative activities of 1GC11-Cu(II), 1GC17-Cu(II), 1GC11$\mathrm{Au}(\mathrm{III})$ and $1 \mathrm{GC17}-\mathrm{Au}(\mathrm{III})$

\begin{tabular}{|c|c|c|c|c|}
\hline & & \multicolumn{3}{|c|}{$\mathrm{IC}_{50}(\mu \mathrm{M})^{[\mathrm{a}]}$} \\
\hline & & HL-60* & HCT116* & $\mathrm{K}^{2} 62^{\star}$ \\
\hline \multirow{4}{*}{ Dendrons } & 1GC11-Cu(II) & $1.93 \pm 1.37$ & $3.37 \pm 0.87$ & $2.36 \pm 0.20$ \\
\hline & 1GC17-Cu(II) & $2.65 \pm 0.65$ & $3.03 \pm 0.254$ & $7.8 \pm 1.28$ \\
\hline & 1GC11-Au(III) & $1.33 \pm 0.25$ & $2.09 \pm 0.23$ & $1.46 \pm 0.04$ \\
\hline & 1GC17-Au(III) & $1.34 \pm 0.30$ & $4.44 \pm 0.87$ & $2.31 \pm 0.20$ \\
\hline \multirow{2}{*}{ Dendrimers } & 1G1-Cu(II) & $1.00 \pm 0.20$ & $3.26 \pm 0.71$ & \\
\hline & 1G1-Au(III) & $0.65 \pm 0.04$ & $2.90 \pm 0.87$ & \\
\hline
\end{tabular}

[a] Cells were incubated dendrons and dendrimes at eight concentrations $(0.01$ to $50 \mu \mathrm{M})$ for $72 \mathrm{~h}$ and the data were represented as "mean $\pm \mathrm{SD}$ " ( $\mathrm{n}=$ $3)$.

In order to extend the panel of cancer cell line profile, we tested the antiproliferative activities of 1GC11-Cu(II), 1GC17-

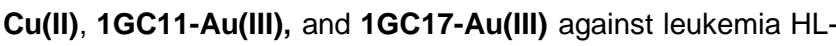
60 , human colon cancer HCT116, and the chronic myeloid leukemia cell line K562. As shown in Table 2, moderate antiproliferative activities were observed regardless of the metal complexed and the length of the alkyl chains, and $\mathrm{IC}_{50}$ S were between $\sim 1.3$ and $\sim 8 \mu \mathrm{M}$. 
Dendron series (generation 1)

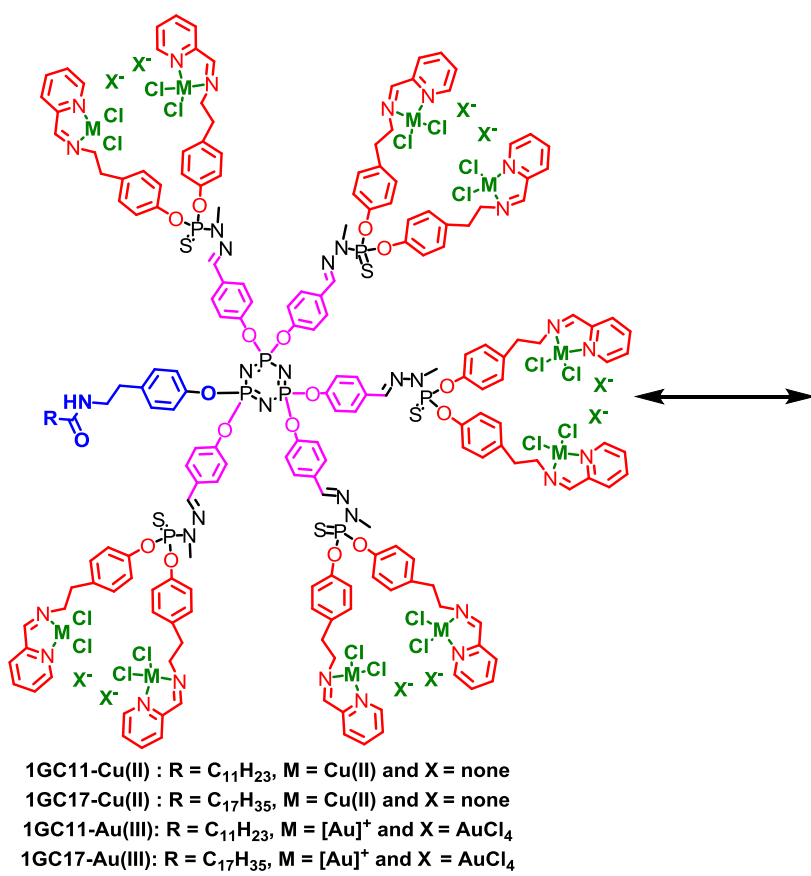

Dendrimer series (generation 1)

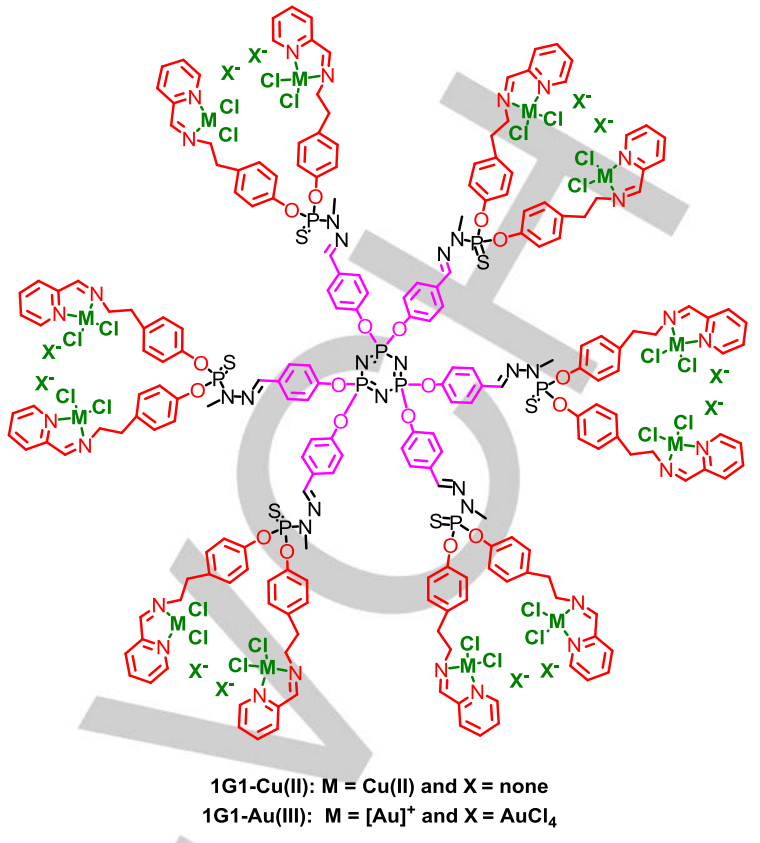

Figure 3. Schematic representation of 1GC11-Cu(II), 1GC17-Cu(II), 1GC11-Au(III), 1GC17-Au(III), 1G1-Cu(II) and 1G1-Au(III).

The next study is the comparison of the antiproliferative activities of the generation 1 metaled phosphorus dendrimers bearing 12 metal groups and the dendrons of generation 1 bearing 10 metal groups (Figure 3). Table 2 presents the antiproliferative activities of the dendrimers 1G1-Cu(II), 1G1$\mathrm{Au}(\mathrm{III})$ and, the dendrons 1GC11-Cu(II), 1GC17-Cu(II), 1GC11$\mathrm{Au}(\mathrm{III})$, and 1GC17-Au(III) against HL-60 and HCT116. The dendrimers 1G1-Cu(II) and 1G1-Au(III) are 2 times more potent $\left(\mathrm{IC}_{50} \mathrm{~s}: 0.65\right.$ and $\left.1 \mu \mathrm{M}\right)$ than the corresponding dendrons 1GC11-Cu(II), 1GC17-Cu(II), 1GC11-Au(III)), and 1GC17$\mathrm{Au}$ (III) against $\mathrm{HL}-60$, and the same potencies have been observed against HCT116. This suggests that the scaffold of dendrimers and dendrons may play a role in regulating the different anticancer activities of the metal complexes.

In order to evaluate the cell death pathway of 1GC11$\mathrm{Cu}(\mathrm{II}), 1 \mathrm{GC17}-\mathrm{Cu}(\mathrm{II}), 1 \mathrm{GC11}-\mathrm{Au}(\mathrm{III})$ and 1GC17-Au(III), several studies were performed including fluorescence imaging studies, flow cytometric analysis and Western blot assays.

4T1 cells were selected due to the potent anti-proliferative activities of 1GC11-Cu(II), 1GC17-Cu(II), 1GC11-Au(III) and 1GC17-Au(III) (Table 1). With the purpose of evaluating the apoptotic features of $4 \mathrm{~T} 1$ cells by the action of phosphorus dendrons with and without metals (9a, 9b, 1GC11-Cu(II), 1GC17-Cu(II), 1GC11-Au(III) and 1GC17-Au(III)), morphological change were analyzed using the fluorescence microscopic imaging technique after $24 \mathrm{~h}$ at two concentrations of phosphorus dendrons, $10 \mu \mathrm{M}$ (Figure 4A) and $20 \mu \mathrm{M}$ (Figure
4B). As shown in Figure 4, significant morphological changes including granular apoptotic bodies and the appearance of membrane blebbing were observed (Figure S11 and S12, experimental section). As shown in Figure 4A, the four metaled phosphorus dendrons enhanced the frequency of apoptotic nuclei in 4T1 cells (marked with an arrow). Clearly, these morphological observations suggested extensive DNA cleavage to produce high molecular weight fragments (HMW) associated with weak chromatin condensation. ${ }^{[15]}$

The rate of the generation and the abundance of HMW fragments significantly depended on the following: 1) apoptotic agent used, 2) the duration of the stimulus, and 3) the cell type considered. ${ }^{[15]}$ In this assay, 4T1 cells were treated with the four different metalated phosphorus dendrons at different concentrations for $24 \mathrm{~h}$. At high concentrations $(20 \mu \mathrm{M})$, metalated phosphorus dendrons stimulated the autophagosome process and the formation of HMW fragments (Figure 4B). These data suggest that the apoptosis is a consequence of direct damage produced on nuclear DNA and autophagosome, highlighting the strong proapoptotic potential of these novel metaled dendrons. In addition, when 4T1 cells were treated with $\mathbf{9 a}$ and $\mathbf{9 b}$, no morphological changes of cells were observed when compared to control cells treated with PBS (Figure S11 and S12). 

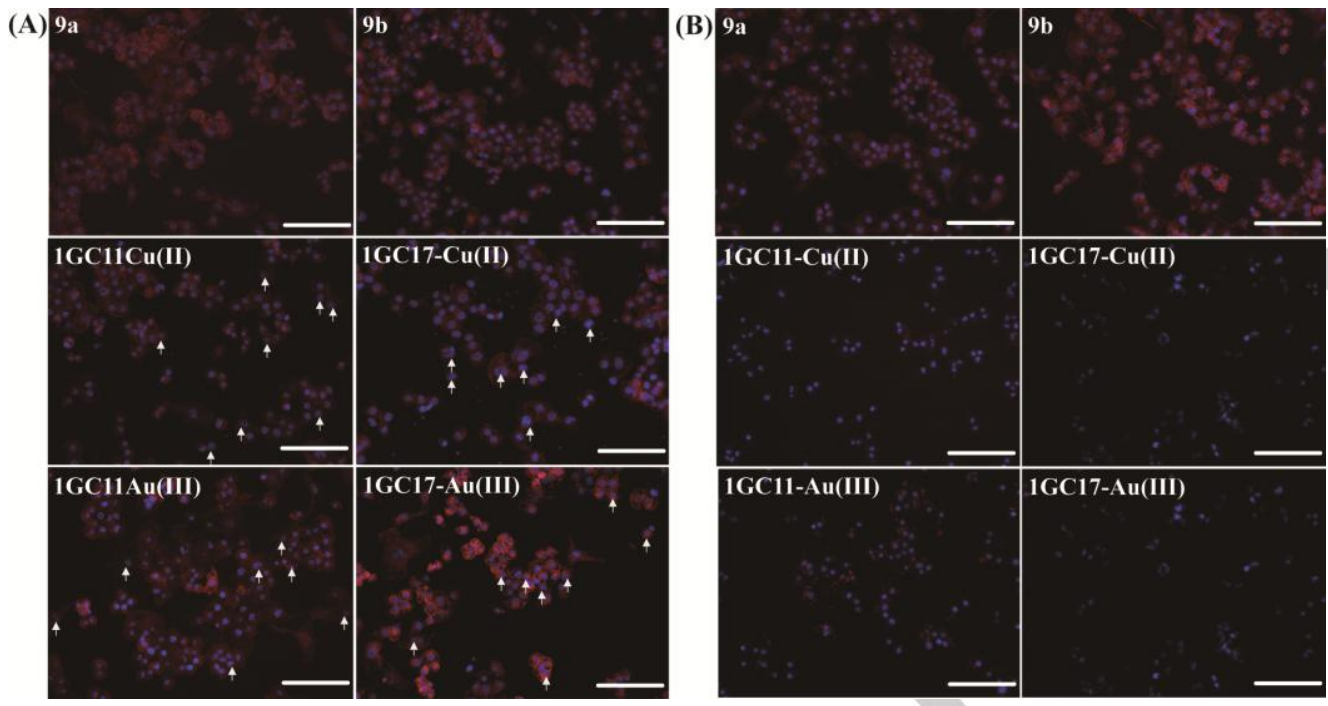

Figure 4. Fluorescence microscopic images of $4 \mathrm{~T} 1 \mathrm{cells}$ treated with 9a, 9b, 1GC11-Cu(II), 1GC17-Cu(II), 1GC11-Au(III)) and 1GC17-Au(III) at 10 $\mu \mathrm{M}$ for $24 \mathrm{~h}$ (A) and at $20 \mu \mathrm{M}$ for $24 \mathrm{~h}$ (B). Scale bar in each panel represents $100 \mu \mathrm{m}$.

It is commonly accepted that the cytotoxicity of antiproliferative agents is primarily associated with cell cycle arrest in $\mathrm{G} 1$, S or G2/M phases which trigger the final apoptosis pathway and cell death. Since metaled phosphorus dendrons displayed the ability to promote autophagosome and apoptotic effects against $4 \mathrm{~T} 1$ cells, we addressed the question about the perturbation effect of the metaled phosphorus dendrons on cellcycle progression. To evaluate this effect, the impact of the metaled dendrons 1GC11-Cu(II), 1GC17-Cu(II), 1GC11-Au(III)) and 1GC17-Au(III) at $10 \mu \mathrm{M}$ was investigated in $4 \mathrm{~T} 1$ cells treated for $24 \mathrm{~h}$. The flow cytometric analysis of the cell cycle distribution is presented in Figure 5A, whereas the percentages of the cellular distribution in different cell cycle phases (G0/G1, $\mathrm{S}$, and $\mathrm{G} 2 / \mathrm{M}$ ) are given in Figure 5B.In the control group, cells contained $2 \mathrm{n}$ chromosomes (phase G0/G1, 45 \%) and few cells were in an active DNA synthesis stage (phase S, 30\%) or already engaged in the mitosis process (phase G2/M, 22 $\%)$. However, for Cu-metaled phosphorus dendrons (1GC11$\mathrm{Cu}(\mathrm{II})$ and $1 \mathrm{GC17}-\mathrm{Cu}(\mathrm{II}))$, cells are in the mitosis phase (S) ( $45 \%$ ) without a substantial increase of the G0/G1 phase after a $24 \mathrm{~h}$ exposure. Particularly, phosphorus dendrons complexed with $\mathrm{Au}$ (III) (1GC11-Au(III) and 1GC17-Au(III)) were more potent promoters of cell cycle arrest than Cu-complexed dendrons in $4 \mathrm{~T} 1$ cells (phase G0/G1, 45\%; phase G2/M, $10 \%$; and phase S, 45\%).

In order to elucidate the molecular mechanism of the cell cycle arrest and apoptosis induced by the metaled phosphorus dendrons using 4T1 cells, the cell cycle- and apoptosis-related proteins were inspected using Western blotting (Figure 5C). The cyclin $E$ protein is regularly synthesized during the cell cycle, reaching a peak in late G1 and early S phase. ${ }^{[16]}$ CyclinECDK2 is essential for the progression through the G1-phase of the cell cycle and initiation of DNA replication (G1- and Sphase transitions). ${ }^{[17]}$ As shown in Figure $5 \mathrm{D}$, for the treatment with 1GC11-Cu(II), 1GC17-Cu(II), 1GC11-Au(III) and 1GC17-
$\mathrm{Au}$ (III) during $24 \mathrm{~h}$, up-regulation of Cyclin $\mathrm{E}$ and weak upregulation of CDK2 were observed. However, for 1GC17-Cu(II), weak up-regulation of Cyclin $\mathrm{E}$ and CDK2 were observed, indicating that the cellular percentage of phase G0/G1 is similar for 1GC17-Cu(II) and the control group ( 45\%). Additionally, the expression of tumor suppressor P53 were also detected. $\mathrm{P} 53$ regulates the cell cycle restriction point which is related to the DNA damage checkpoint. In response to DNA damage, P53 is activated and turns on transcription of one of its downstream genes, then the downstream genes activate cyclin-Cdk complexes to stop DNA replication. ${ }^{[18]}$ After treatment of the cells with metaled phosphorus dendrons, the cells displayed a high level of P53 versus the control group. Previous experiments showed that up-regulation of P53 induces G2/M cell cycle arrest. ${ }^{[19]}$ Consequently, the metalated dendrons influenced the expressions of cell cycle regulatory proteins which altered the cell cycle distribution. In addition, the expression of cytochrome C (Cyto C), Caspases-3, and Bax were also detected. Caspases-3 are known to play a pivotal role in both initiation and execution of apoptosis. ${ }^{[20]}$ It has been reported that caspase-dependent apoptosis requires the release of proteins sequestered in the mitochondria of cancer cells but the high inner membrane potential prevents the opening of mitochondrial pores. ${ }^{[20]}$ One of the key controls to open the mitochondrial membrane pores is the regulation of the level of Bax. ${ }^{[21]}$ During the $24 \mathrm{~h}$ treatment with 1GC11-Au(III)) and 1GC17-Au(III), the cells displayed up-regulation of Cyto C, Caspase-3, and Bax, while 4T1 cells treated with the $\mathrm{Cu}(\mathrm{II})$ dendrons did not display significative changes in the regulation of Cyto C, Caspase-3 and Bax when compared to the control cells treated with PBS. In a nutshell, the 4T1 cells treated with $\mathrm{Au}$ (III)-dendrons exhibited higher levels of caspase-3 and Bax than the group of $\mathrm{Cu}(\mathrm{II})$-dendrons. 

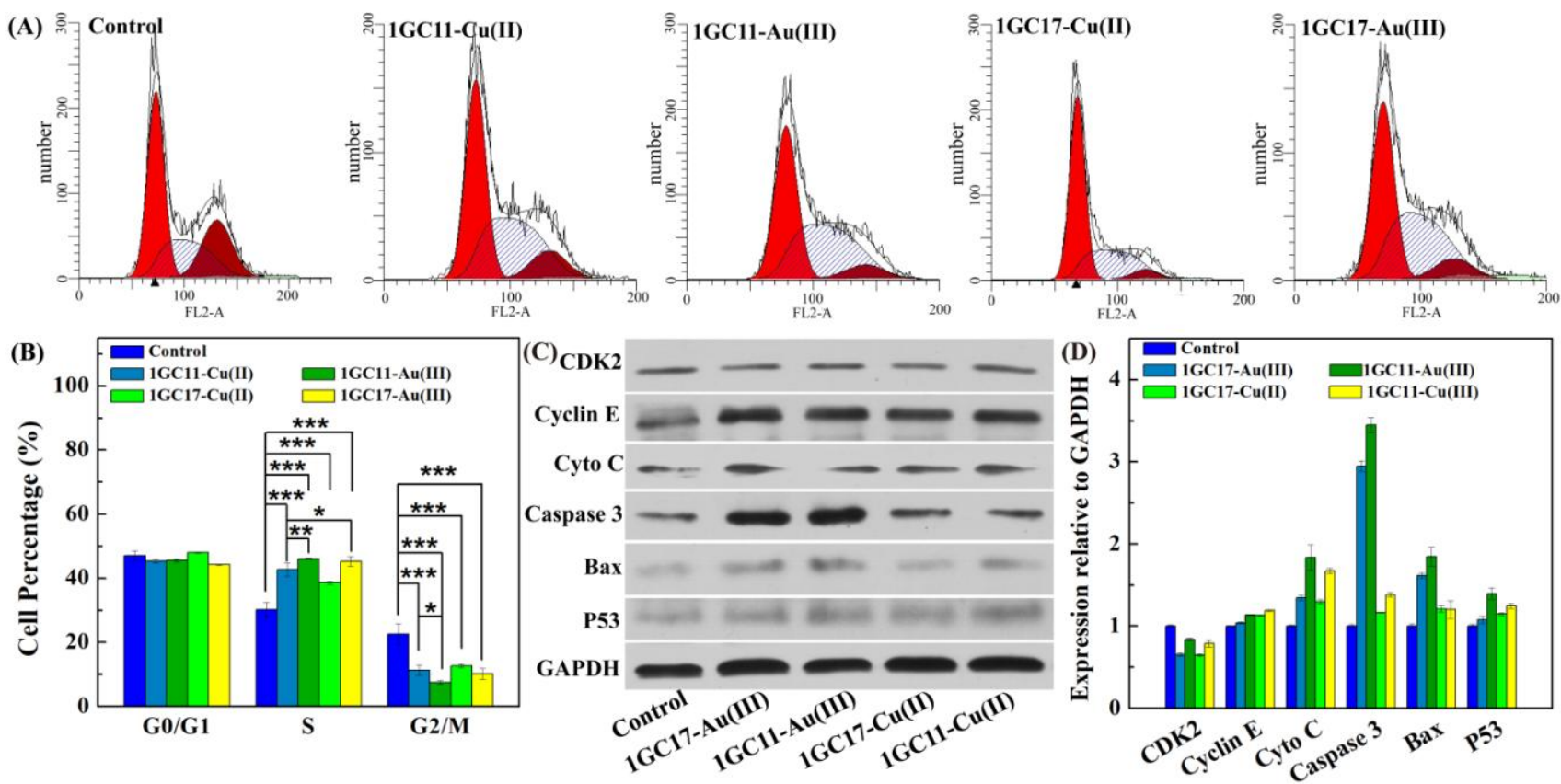

Figure 5. (A) Cell cycle analysis of the 4T1 cells after incubation with 1GC11-Cu(II), 1GC17-Cu(II), 1GC11-Au(III)) and 1GC17-Au(III) at the dendrons concentration of $10 \mu \mathrm{M}$ for $24 \mathrm{~h}$; (B) The percentages of the cellular distribution in different cell cycle phases of the 4T1 cells; (C) Western Blot assay of the expression of protein related to $S$ phase and apoptosis in $4 \mathrm{~T} 1$ cells after incubation with different dendrons ([dendron] $=10 \mu \mathrm{M}$ ) for $24 \mathrm{~h}$. The GAPDH protein was used as a reference; (D) Relative protein expression levels in $4 \mathrm{~T} 1$ cells after incubation with the different dendrons ([dendron] $=10 \mu \mathrm{M}$ ) for $24 \mathrm{~h}$.

Taken together, these studies demonstrated that the dendrons complexed with $\mathrm{Au}(\mathrm{III})$ increased the cellular lethality (4T1 cells) and the cell death pathway is related to caspasedependent process, promoting the translocation of Bax to the mitochondria and then the release of Cyto $\mathrm{C}$, inducing the activation of the apoptosis process.

Table 3. General view of cell death pathway of phosphorus dendrons prepared in this study in comparison with the corresponding dendrimers.

\begin{tabular}{lcc}
\hline \multicolumn{1}{c}{ Nanoparticles } & $\begin{array}{c}\text { Translocation of } \\
\text { Bax }\end{array}$ & $\begin{array}{c}\text { Caspase-3 } \\
\text { activation }\end{array}$ \\
\hline Phosphorus dendrons & Strong effect (4T1): & Weak effect (4T1): \\
& 1GC11-Au(III)) and & 1GC11-Cu(II), \\
& 1GC17-Au(III) & 1GC17-Cu(II) \\
Phosphorus & Strong effect (KB & Strong effect (KB \\
dendrimers $^{[2]}$ & and HL60): & and HL60): 1G3 \\
& $1 \mathrm{G3}-\mathrm{Cu}(\mathrm{II})$ & \\
\hline
\end{tabular}

To sum up, Au(III)-complexed dendrons (1GC11-Au(III) and 1GC17-Au(III)) clearly demonstrated their ability to promote cell death in a caspase-dependent pathway by facilitating the translocation of Bax to the mitochondria and the release of Cyto $\mathrm{C}$, whereas $\mathrm{Cu}$ (II)-complexed dendrons (1GC11-Cu(II) and 1GC17-Cu(II)) are weak activators of caspase-3. Also, copper-based dendrons showed weak antiproliferative activities in contrast with $\mathrm{Au}$ (III)-complexed ones. Table 3 summarizes the mechanism of actions of the phosphorus dendrons 1GC11-Cu(II), 1GC17-Cu(II), 1GC11$\mathrm{Au}(\mathrm{III})$ and 1GC17-Au(III) versus phosphorus dendrimers 1G3 and 1G3-Cu.

\section{Conclusion}

In summary, first-in-class $\mathrm{Cu}$ (II) and $\mathrm{Au}$ (III) metaled phosphorus dendrons (generation 1) bearing $10 \mathrm{Cu}(\mathrm{II}) \mathrm{Cl}_{2}$ or $\left[\mathrm{Au}(\mathrm{III}) \mathrm{Cl}_{2}\right]^{+}$on their surface, and with $\mathrm{C}_{11} \mathrm{H}_{23}$ and $\mathrm{C}_{17} \mathrm{H}_{35}$ linear alkyl chains were synthesized, and showed significant antiproliferative activity against cancer cell lines such as 4T1 and MCF-7 (breast cancer). The complexation of phosphorus dendrons with $\mathrm{Cu}(\mathrm{II})$ or $\mathrm{Au}(\mathrm{III})$ boosts its antiproliferative activity compared to nonmetallic dendrons. The safety ratio depends on the metal, the nature of the alkyl chain, and the nature of the normal cells used. The antiproliferative activities against 4T1 and MCF-7 cells showed $\mathrm{IC}_{50}$ s between 0.6 and $2.8 \mu \mathrm{M}$. Similar to the phosphorus dendrimers, the replacement of $\mathrm{Cu}$ (II) by $\mathrm{Au}$ (III) strongly improved the anti-proliferative activities. 1GC11$\mathbf{A u}$ (III) and 1GC17-Au(III) dendrons showed $\mathrm{IC}_{50}$ S of $\sim 0.16-0.8$ $\mu \mathrm{M}$ against $4 \mathrm{~T} 1$ and MCF-7 cells. In addition, short alkyl chain length of the dendrons renders $\mathrm{Au}$ (III) complexes with more significant antiproliferative activity to kill cancer cells. Cell death pathway analysis reveals that the metaled dendrons could alter the cell cycle- and apoptosis-related protein status of cells, resulting in cell cycle S-phase arrest and apoptosis. In particular, $\mathrm{Au}(\mathrm{III})$-complexes induced the caspase-dependent cellular lethality by promoting the translocation of Bax to the mitochondria and the release of Cyto $\mathrm{C}$, whereas the $\mathrm{Cu}(\mathrm{II})$ complexes are weak activators of caspase-3, in line with their moderate antiproliferative activity in cancer cells. 
Taken together, these studies showed that these first-inclass metaled phosphorus dendrons represent a novel class of anticancer nano-drugs, and their development will open new avenue to tackle cancer. We thus ought to see the emergence of novel dendron-based particles to be applied against difficult diseases such as cancers and distant metastases.

\section{Acknowledgements}

This research is financially supported by the National Natural Science Foundation of China (21911530230, 21773026, and 81761148028) and Sino-French Cai Yuanpei Programme. S. Mignani and X. Shi acknowledges the support of FCT Fundacao para a Ciencia e a Tecnologia with Portuguese Government funds through the CQM Strategic Project PEst-OE/ QUI/UI0674/2013, and ARDITI-Agencia Regional parao Desenvolvimento da Investigacao Tecnologia through the project M1420-01-0145-FEDER-000005 - Centro de Quımica da Madeira - CQM+ (Madeira 14-20 Program). J-P. Majoral, AM. Caminade and R. Laurent thank the CNRS (France) for financial support.

\section{Conflict of interest}

There are no conflicts to declare.

Keywords: anti-proliferative activities $\cdot$ metaled phosphorus dendrons $\bullet$ fluorescence imaging $\bullet$ flow cytometric analysis
[17] J. Harbour, R. X. Luo, A. D. Santi, A. A. Postigo and D. C. Dean, Cell $1999,98,859-869$

[18] A. J. Levine, Cell 1997, 88, 323-331.

[19] a) Y. Li, L. P. Zhang, F. Dai, W. J. Yan, H. B. Wang, Z. S. Tu and B. Zhou, J. Agric. Food Chem. 2015, 63, 7731-7742; b) S. Mignani, N. E Brahmi, L. Eloy, J. Poupon, V. Nicolas, A. Steinmetz, S. El Kazzouli, M. M. Bousmina, M. Blanchard-Desce, A. M. Caminade, J. P. Majoral and T. Cresteil, Eur. J. Med. Chem. 2017, 132, 142-156.

[20] A. G. Porter and R. U. Jänicke, Cell Death Differ. 1999, 6, 99-104.

[21] a) J. M. Jurgensmeier, Z. H. Xie, Q. Deveraux, L. Ellerby, D. Bredesen and J. C. Reed, Proc. Natl. Acad. Sci. U. S. A. 1998, 95, 4997-5002; b) R. Eskes, B. Antonsson, A. Osen-Sand, S. Montessuit, C. Richter, R Sadoul, G. Mazzei, A. Nichols and J. C. Martinou, J. Cell Biol. 1998, 143 217-224; c) M. Narita, S. Shimizu, T. Ito, T. Chittenden, R. J. Lutz, H. Matsuda and Y. Tsujimoto, Proc. Natl. Acad. Sci. U. S. A. 1998, 95 $14681-14686$.

[22] a) N. Brahmi, S. Kazzouli, S. M. Mignani, E. M. Essassi, G. Aubert, R Laurent, A. M. Caminade, M. M. Bousmina, T. Cresteil and J. P. Majoral Mol. Pharmaceutics 2013, 10, 1459-1464; b) S. M. Mignani, N. Brahmi, S. Kazzouli, R. Laurent, S. Ladeira, A. M. Caminade, E. PedziwiatrWerbicka, E. M. Szewczyk, M. Bryszewska, M. M. Bousmina, T. Cresteil and J. P. Majoral, Mol. Pharmaceutics 2017, 14, 4087-4097.

[1] U. Jungwirth, C. R. Kowol, B. K. Keppler, C. G. Hartinger, W. Berger and P. Heffeter, Antioxid. Redox Signaling 2011, 15, 1085-1127.

[2] M. Frezza, S. Hindo, D. Chen, A. Davenport, S. Schmitt, D. Tomco and Q. P. Dou, Curr. Pharm. Des. 2010, 16, 1813-1825.

[3] Q. Du, L. H. Guo, X. X. Ge, L. P. Zhao, Z. Z. Tian, X. C. Liu, F. J. Zhang and Z. Liu, Inorg. Chem. 2019, 58, 5956-5965.

[4] V. Milacic, D. Fregona and Q. P. Dou, Histol. Histopathol. 2008, 23, $101-$ 108.

[5] a) T. C. Karlenius and K. F. Tonissen, Cancers 2010, 2, 209-232; b) M. Arredondo and M. T. Nunez, Mol. Aspects Med. 2005, 26, 313-327; c) K. Balamurugan and W. Schaffner, Biochim. Biophys. Acta, Mol. Cell Res. 2006, 1763, 737-746.

[6] a) M. Ferrari, Nat. Rev. Cancer 2005, 5, 161-171; b) D. B. Buxton, Wires Nanomed Nanobi 2009, 1, 149-155; c) P. Hassanzadeh, F. Atyabi and R. Dinarvand, Life Sci. 2017, 182, 93-103.

[7] a) Y. Barenholz, J. Controlled Release 2012, 160, 117-134; b) C. M. Dawidczyk, C. Kim, J. H. Park, L. M. Russell, K. H. Lee, M. G. Pomper and P. C. Searson, J. Controlled Release 2014, 187, 133-144.

[8] N. Launay, A. M. Caminade and J. P. Majoral, J. Organomet. Chem. 1997, 529, 51-58.

[9] S. M. Grayson and J. M. J. Frechet, Chem. Rev. 2001, 101, 3819-3867.

[10] Y. Cheng, L. Zhao, Y. Li and T. Xu, Chem. Soc. Rev. 2011, 40, 26732703.

[11] M. Gouveia, J. Figueira, M. G. Jardim, R. Castro, H. Tomas, K. Rissanen and J. Rodrigues, Molecules 2018, 23.

[12] N. Brahmi, S. Kazzouli, S. M. Mignani, E. M. Essassi, G. Aubert, R. Laurent, A. M. Caminade, M. M. Bousmina, T. Cresteil and J. P. Majoral, Mol. Pharmaceutics 2013, 10, 1459-1464.

[13] N. S. Del Olmo, R. Carloni, A. M. Bajo, P. Ortega, A. Fattori, R. Gomez, M. F. Ottaviani, S. Garcia-Gallego, M. Cangiotti and F. J. de la Mata, Nanoscale 2019, 11, 13330-13342.

[14] S. M. Mignani, N. Brahmi, S. Kazzouli, R. Laurent, S. Ladeira, A. M. Caminade, E. Pedziwiatr-Werbicka, E. M. Szewczyk, M. Bryszewska, M. M. Bousmina, T. Cresteil and J. P. Majoral, Mol. Pharmaceutics 2017, 14, 4087-4097.

[15] M. Coronnello, E. Mini, B. Caciagli, M. A. Cinellu, A. Bindoli, C. Gabbiani and L. Messori, J. Med. Chem. 2005, 48, 6761-6765.

[16] J. M. Roberts, A. Koff, K. Polyak, E. Firpo, S. Collins, M. Ohtsubo and J. Massague, Cold Spring Harbor Symp. Quant. Biol. 1994, 59, 31-38. 


\section{Entry for the Table of Contents}

\section{RESEARCH ARTICLE}

First-in-class $\mathrm{Cu}(\mathrm{II})$ and $\mathrm{Au}(\mathrm{III})$ metaled phosphorus dendrons were developed and displayed potent anticancer activity stemming from different cell death pathways. $\mathrm{Cu}(\mathrm{II})$ metaled dendrons showed a potent caspase-dependent cell death pathway; whereas $\mathrm{Au}$ (III) metaled dendrons displayed a caspase-independent apoptotic pathway. These metaled phosphorus dendrons represent a novel class of anticancer nano-drugs, and their development will open new avenue to tackle cancer.

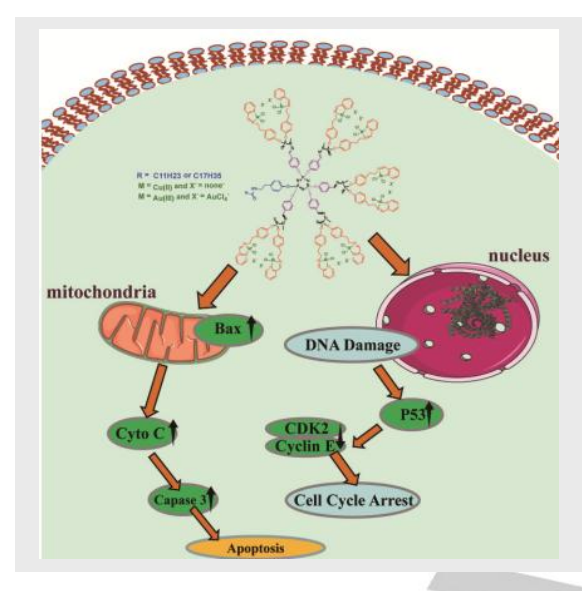

Liang Chen, Yu Fan, Jieru Qiu, Régis Laurent, Jin Li, Jérôme Bignon, Serge Mignani, ${ }^{*}$ Anne-Marie Caminade, Xiangyang Shi* and Jean-Pierre Majoral* $^{*}$

\section{Page No. - Page No.}

Potent antitumoral efficacy of first-inclass $\mathrm{Cu}$ (II) and $\mathrm{Au}$ (III) metaled phosphorus dendrons with distinct cell death pathways 